\title{
Educational Possibilities of Video Games in the Primary Education Stage According to Teachers in Training. A Case Study
}

\author{
Verónica Marín-Díaz ${ }^{* *}$ (D) Marina Morales-Díaz², Eloísa Reche-Urbano³ \\ ${ }^{1}$ College of Education Sciences, University of Córdoba, Spain \{vmarin@uco.es\} \\ Sagrado Corazon College of Education, University of Córdoba Spain \{m.morales@magisteriosc.es\} \\ ${ }^{3}$ Sagrado Corazon College of Education, University of Córdoba Spain \{fe1reure@uco.es\} \\ Received on 11 June 2018; revised on 18 June 2018; accepted on 18 July 2018; published on 15 January 2019
}

DOI: $10.7821 /$ naer.2019.1.330

(c) BY-NC-ND

\begin{abstract}
Education mediated by video games is a way of working that is increasingly more evident. Along this line we present the results obtained from a group of pre-service teachers $(\mathrm{N}=169)$, who through a quasi-experimental study and the use a questionnaire with 62 items, with a scale to answer to 5 Likert-type, created from Marín and Martín (2014) and Marín (2016), have reflected that previous experience in the utilisation of video games, which are not educational, is a key element to gaining a position of acceptance for their use and for developing the curriculum at the Primary Education level. It has also been possible to conclude the existence of some significant differences regarding gender in some aspects related to the curricular mediation of video games in which males are more inclined towards their use, as well as in regard to their personal relationship with this theme. Therefore, it can be inferred that video games can be used in the education of children at the primary stage.
\end{abstract}

KEYWORDS: VIDEOGAMES, UNIVESITY STUDENT, LEARNING, PRIMARY EDUCATION.

\section{STATE OF THE QUESTION}

The development of learning at the primary levels of education is today mediated by the use of information and communication technologies (ICT) in general and in particular of the various digital tools, many of which are created under the protection of Internet development-.

Along this line of innovation and research we find works that present the viability of digitized education as well as a type of learning that we could call 2.0, which has highlighted that both well understood and properly used technological resources can provide more benefits than prejudices to such training, as is reflected in some research and experiences (Cámara, Ortega \& Tudela, 2017; Cañón, Cantón, Arias, \& Baelo, 2017; Loza, Salinas, \& Glasserman, 2017; del Moral \& Fernández, 2015; Morales, Trujillo \& Raso, 2016; Tarancón, 2017). In general, in all we see that the technological variable is relevant as a resource on which the teaching methodology is based.

\footnotetext{
*To whom correspondence should be addressed:

Universidad de Córdoba, Facultad de Ciencias de la Educación,

Avda. San Alberto Magno s/n, 14004, Córdoba , Spain
}

Focusing on videogames, the divergences around their satisfactory performance in the academic field are latent, since there are studies that affirm the benefits of their use (DeCamp \& Ferguson, 2017; Marín \& Martín, 2014; del Moral, Guzmán, \& Fernández, 2018), and those who draw a picture of violent behavior generation (Anderson \& Gentile, 2014; Greitemeyer, 2018) for example. But, if, a priori, we consider, as pointed out by Moral and Fernández (2015), that video games have been designed to be used in a playful and / or entertainment act, not for the development of a teaching and learning process, these differences of thought do not have to become more evident, given that some research indicates that their employment in the academic-educational field can be beneficial (Adukaite van Zyl, Er, \& Cotani, 2017; Aznar-Díaz, Raso-Sánchez, \& Hinojo -Lucena, 2017; Barr, 2017; Marín \& Sampedro, 2016; Martín 2015), hence the learning aspect based of digital games (ABJD) is gaining more and more strength (Herrero, del Moral, \& Torralba-Burrial, 2017 ).

From this friendly perspective of videogames we present the following research, which tries to highlight how pre-service teachers denote the benefits of this resource for learning in the first stage.

\section{METHOD}

In line with the research carried out by Adukaite et al. (2017) with university students of Tourism, in this investigation we intend to determine if the use of video games can improve the learning process of Primary Education students. For this reason, we have positioned ourselves in a positivist paradigm within a quasi - experimental method (Sabariego, 2012).

\subsection{Data Collection Instrument}

To collect the data, the survey technique was used and specifically the questionnaire. Its design started with that employed by Marín and Martín (2014) and Marín (2016). The questionnaire consisted of 62 items, distributed in 3 dimensions. The first one was the identification of the participants: gender, age, course, device with which they usually play, the number of hours they play during the week and the weekend, if they usually play alone or accompanied by others, if they play with their school team mates, if they play on the net and finally if they know their teammates. Next, the set that refers to video games and the Primary Education classroom (dimension 2), followed by their 
attitude toward video games (dimension 3). The response scale was the Likert type of 5 points, where 1 corresponded to 'Nothing' and 5 to 'Too Much' $(2=$ little, $3=$ enough and $4=$ a lot $)$.

The administration of the questionnaire was carried out at the following intervals: firstly, the theoretical explanation on videogames and education was carried out and secondly, the administration of the instrument.

\subsection{Validation and reliability of the instrument}

In order to determine the validity and reliability of the questionnaire, it was subjected to various tests. The construct validity was carried out through an exploratory factor analysis, maximum likelihood extraction method and varimax rotation, the previous calculation of the Kaiser-Meyer and Olkin index (KMO $=.777)$, the Bartlett sphericity test $(\mathrm{p}<0.000)$ which denotes significance; on the other hand, the generated factor agrees on the hypothetical dimensions proposed in the construct that is trying to be measured, in the first factor the saturating items are those relative to the valuation, explaining $71 \%$ of the total variance.

With regard to content validity, judges were tested among teachers in Primary Education.

The following criteria were applied for the selection of the same: more than 5 years of experience an this level of education, knowledge beyond the level of ICT user, use of digital resources in the classroom and easy access to teachers. The sample was finally formed of 39 teachers from the city of Cordova, where, $89.7 \%$ were women and $10.3 \%$ were men. $2.6 \%$ had more than 25 years of work experience, $15.8 \%$ between 21 and $25,55.3 \%$ between 16 and 20,21.1\% between 11 and 15 years and $5.3 \%$ only had between 5 and 10 years of professional experience. With regard to ICT, $100 \%$ had knowledge of it as well as using it in their classes.

Focusing our attention on the use of video games in the Primary Education classroom, teachers reflected their use in their leisure time. $30.8 \%$ of them play one hour a week whereas $35.9 \%$ never play.

Regarding the purpose of their work, the evaluations made to the questionnaire were related to the writing of the items, indicating that they should have been written in a personal way, which caused the re-elaboration of all the items. Finally, they also indicated that the instrument was excessively long, although in children at this educational level it could be administered at two points, depending on the dimensions in which the judges distributed the items generating two dimensions, the first one in which the data of the sample description was reflected, previously established by us (Videogames and primary education) and the second one, called "Attitude towards videogames", in which they integrated the items that were more aimed at determining the behavior of each individual when dealing with a video game. In this way the dimensions were made up of 35 and 13 respectively.

With respect to the reliability of the instrument, the Cronbach alpha was carried out, obtaining a value of .901, the reason why it is considered to be very high (Mateo, 2012). Considering both dimensions in which the items are grouped, we subsequently analyzed the reliability of each one of them $(.908$ and .813), we see that both dimensions maintained high values (Mateo, 2012), confirming the reliability of the instrument.

\subsection{Population and Sample}

The population being studied was composed of all the pre-service teachers of the Degree in Primary Education of the University of
Córdoba. The sample selection process follows an incidental mode and convenience, given that the premise was students that were studying the technology subjects that the aforementioned university offers in the degrees in Primary Education, both the Spanish and bilingual modalities.

The participating sample consisted of 169 students, where $64.9 \%$ were men and $35.1 \%$ were women.

Considering the age, the sample was distributed in the following way: $94.7 \%$ of the teachers in training were between $20-25$ years old, $2.3 \%$ are between 26 and 35 , and $0.6 \%$ are more than 36 years old.

Concerning the devices that they use for playing video games, $56.1 \%$ employ their mobile phone, while $18.7 \%$ use a Tablet, $13.5 \%$ use video consoles and, finally, $11.1 \%$ play on the computer (both laptop and desktop).

Regarding the time that pre-service teachers claim to spend playing video games (Table 1), we found that both $26.3 \%$ and $26.9 \%$ play for one hour in both periods of time (during the week and on weekends). It is significant that $19.9 \%$ affirm they play for more than five hours during the week and $9.9 \%$ on the weekend. It is striking that $18.1 \%$ and $25.1 \%$ attest they do not play at all during the week or on weekends.

Table 1. Hours of spent gaming

\begin{tabular}{lcc}
\hline & H. week & H. weekend \\
\hline No hour & 18.1 & 25.1 \\
Fifteen minutes & 0.6 & 2.3 \\
Thirty minutes & 2.9 & 5.3 \\
One hour & 26.3 & 26.9 \\
An hour and a half & 0 & 0.6 \\
Two hours & 16.4 & 14.0 \\
Two hours and half & 0 & 0.6 \\
Three hours & 8.2 & 11.1 \\
Four hours & 7.6 & 4.1 \\
More than five hours & 19.9 & 9.9 \\
\hline
\end{tabular}

Focusing our attention on the game mode (alone or accompanied, by peers, in a network,...) $62.2 \%$ play alone while $35.7 \%$ play accompanied by others. $35.5 \%$ play online, compared to $47.3 \%$ who do not and $17.2 \%$ who say they do it sometimes. It is also emphasized that playing with schoolmates is represented by $9.4 \%$ if they do, $66.1 \%$ do not and $24.6 \%$ if they sometimes play with their classmates. After being questioned about the knowledge they have of their online playmate, they indicate that $13.5 \%$ do know them and $52 \%$ do not, while $28.1 \%$ indicate that they do not know them sometimes.

If we look at the gender contingency and hours of play spent during the week (Table 2) and at weekends (table 3) we see that men, both during the week and on weekends either play more than 5 hours $(24 \%)$ or play an average of 1 hour and 5 hours (16\%) compared to $10 \%$ of women and $32 \%$ of them who do not play on weekends or for 1 hour ( $31 \%)$. 
Table 2. Gender contingency * hours played per week

\begin{tabular}{lcc}
\hline & WOMAN & MEN \\
\hline No hour & $24 \%$ & $7 \%$ \\
Fifteen minutes & $1 \%$ & $0 \%$ \\
Thirty minutes & $5 \%$ & $0 \%$ \\
One hour & $34 \%$ & $11 \%$ \\
Two hours & $20 \%$ & $8 \%$ \\
Three hours & $5 \%$ & $9 \%$ \\
Four hours & $6 \%$ & $7 \%$ \\
More than five & $10 \%$ & $24 \%$ \\
\hline
\end{tabular}

Table 3. Gender contingency * hours played at the weekend

\begin{tabular}{lcc}
\hline & WOMAN & MEN \\
\hline No hour & $32 \%$ & $11 \%$ \\
Fifteen minutes & $3 \%$ & $1 \%$ \\
Thirty minutes & $7 \%$ & $2 \%$ \\
One hours & $31 \%$ & $16 \%$ \\
Two hours & $18 \%$ & $7 \%$ \\
Three hours & 95 & $10 \%$ \\
Four hours & $4 \%$ & $3 \%$ \\
More than five hours & $1 \%$ & $16 \%$ \\
\hline
\end{tabular}

\section{RESULTS}

\subsection{Descriptive study}

The descriptive study carried out according to the dimensions, shows that in the first (Videogame and Primary classroom) (Table 4) teachers in training are in a positive (enough) position towards the presence of videogames in the development of the curriculum of Primary Education in 19 of the 35 items that comprise it, because they promote behaviors such as those indicated in item 10 (You believe in equal rights between men and women), 12 (It allows you to master the language of your autonomous community (if any) ), 16 (It helps in mental operations and calculation which is knowledge that you can apply to everyday life) 27 (It helps to develop an attitude contrary to violence) and 30 (They promote an attitude to prevent traffic accidents). However, they highlight item 9 (Discrimination against people with disabilities) and 14 (It helps you work properly in everyday situations using a foreign language) in which participants reveal a disagreement that video games improve or prevent such behaviors.
Table 4. Descriptive study dimension 1

\begin{tabular}{|c|c|c|c|c|c|c|c|}
\hline & \multirow{2}{*}{ M. } & \multirow{2}{*}{ D.T. } & \multicolumn{5}{|c|}{$\%$} \\
\hline & & & 1 & 2 & 3 & 4 & 5 \\
\hline 1 & 3.33 & .847 & 1.2 & 17 & 33.3 & 44.4 & 4.1 \\
\hline 2 & 3.22 & 1.010 & 4.1 & 21.1 & 32.2 & 33.9 & 8.8 \\
\hline 3 & 3.45 & .862 & 1.8 & 12.3 & 32.2 & 46.6 & 7 \\
\hline 4 & 3.66 & .768 & & 7.6 & 29.2 & 52.6 & 10.5 \\
\hline 5 & 3.29 & .940 & 1.8 & 19.4 & 35.3 & 34.7 & 8.8 \\
\hline 6 & 3.51 & 1.042 & 2.9 & 15.8 & 25.7 & 38.6 & 17 \\
\hline 7 & 3.56 & .946 & 1.2 & 12.3 & 32.7 & 37.4 & 16.4 \\
\hline 8 & 3.61 & 1.053 & 5.8 & 6.4 & 27.5 & 40.9 & 19.3 \\
\hline 9 & 1.74 & 1.595 & 71.9 & 7.6 & 7.6 & 5.8 & 6.4 \\
\hline 10 & 3.89 & 1.190 & 6.4 & 7.6 & 15.2 & 32.2 & 38.6 \\
\hline 11 & 3.72 & .959 & 2.4 & 8.9 & 23.1 & 46.2 & 19.5 \\
\hline 12 & 3.75 & 1.005 & 1.8 & 9.4 & 26.9 & 35.7 & 26.3 \\
\hline 13 & 3.34 & .928 & 1.8 & 17 & 36.3 & 35.7 & 9.4 \\
\hline 14 & 2.78 & .996 & 7.1 & 36.5 & 33.5 & 17.6 & 5.3 \\
\hline 15 & 3.63 & 2.444 & 1.8 & 12.3 & 35.1 & 38.6 & 11.7 \\
\hline 16 & 3.77 & .895 & 1.2 & 7.6 & 24 & 47.4 & 19.9 \\
\hline 17 & 3.15 & .944 & 1.8 & 25.1 & 37.4 & 28.1 & 7.6 \\
\hline 18 & 3.53 & .849 & .6 & 12.3 & 30.4 & 47.4 & 9.4 \\
\hline 19 & 3.47 & .815 & .6 & 11.2 & 36.5 & 44.1 & 7.6 \\
\hline 20 & 3.46 & .849 & .6 & 11.7 & 38.6 & 39.2 & 2.9 \\
\hline 21 & 3.70 & .832 & & 7.6 & 31 & 45 & 16.4 \\
\hline 22 & 3.16 & 1.022 & 3.5 & 24.6 & 33.9 & 28.1 & 9.9 \\
\hline 23 & 3.21 & .959 & 1.2 & 24.6 & 35.7 & 29.2 & 9.7 \\
\hline 24 & 3.71 & .930 & .6 & 8.8 & 31.6 & 36.8 & 22.2 \\
\hline 25 & 3.67 & .846 & .6 & 8.2 & 29.2 & 47.4 & 14.6 \\
\hline 26 & 3.58 & .945 & 1.8 & 11.1 & 30.4 & 40.9 & 15.8 \\
\hline 27 & 3.76 & 1.038 & 2.3 & 11.7 & 19.3 & 40.9 & 25.7 \\
\hline 28 & 3.72 & .947 & 1.8 & 8.2 & 27.5 & 41.5 & 21.1 \\
\hline 29 & 3.63 & 1.062 & 3.5 & 13.5 & 19.9 & 42.7 & 20.5 \\
\hline 30 & 3.97 & 1.060 & 3.5 & 5.3 & 20.5 & 32.2 & 38.6 \\
\hline 31 & 3.68 & .909 & 1.2 & 10.1 & 24.9 & 47.3 & 16.6 \\
\hline 32 & 3.59 & .896 & 1.8 & 9.5 & 30.2 & 45.6 & 13 \\
\hline 33 & 3.67 & .808 & 1.8 & 4.8 & 29.2 & 53 & 11.3 \\
\hline 34 & 3.38 & .888 & 2.4 & 13.1 & 35.7 & 41.7 & 7.1 \\
\hline 35 & 3.42 & .945 & 3.6 & 11.9 & 32.7 & 42.3 & 9.5 \\
\hline
\end{tabular}

In dimension two we found that the personal attitude of teachers in training towards video games is that they barely like them (item 36) and that these do not benefit academic performance (items 47 and 48), however, they do like educational video games (item 45). 
Table 5. Descriptive study dimension 2

\begin{tabular}{lrrrrrrr}
\hline & M. & D.T. & \multicolumn{6}{c}{ \% } \\
\cline { 4 - 8 } & & & \multicolumn{1}{c}{$\mathbf{1}$} & \multicolumn{1}{c}{$\mathbf{2}$} & $\mathbf{3}$ & \multicolumn{1}{c}{$\mathbf{4}$} & \multicolumn{1}{c}{$\mathbf{5}$} \\
\hline 36 & 2.96 & 1.014 & 4.1 & 33.7 & 31.4 & 23.7 & 7.1 \\
37 & 1.51 & .882 & 67.3 & 22 & 4.8 & 4.8 & 1.2 \\
38 & 1.85 & 1.868 & 56.8 & 23.7 & 10.7 & 5.9 & 3 \\
39 & 1.39 & .725 & 72.2 & 18.9 & 7.1 & 1.2 & .6 \\
40 & 2.00 & 1.063 & 41.4 & 30.2 & 17.2 & 9.5 & 1.8 \\
41 & 1.33 & .730 & 78.1 & 14.2 & 4.7 & 2.4 & .6 \\
42 & 1.70 & 1.045 & 60.4 & 20.7 & 10.1 & 6.5 & 2.4 \\
43 & 1.40 & .825 & 75.1 & 16 & 4.1 & 3.6 & 1.2 \\
44 & 1.58 & 1.000 & 67.3 & 17.9 & 7.1 & 5.4 & 2.4 \\
45 & 2.81 & 1.052 & 10.7 & 27.2 & 39.6 & 15.4 & 7.1 \\
46 & 2.34 & 1.096 & 24.9 & 36.1 & 23.7 & 11.2 & 4.1 \\
47 & 2.08 & .919 & 29 & 43.2 & 19.5 & 7.7 & .6 \\
\hline 48 & 2.79 & 1.349 & 20.7 & 26.6 & 19.5 & 18.9 & 14.2 \\
\hline
\end{tabular}

\subsection{Inferential study}

To determine the existence or not of differences according to the gender variable and the device of use for playing, two tests have been performed, Students T $(p=0.05)$ for related samples with respect to the first one and Analysis of the Variance (ANOVA) for the second one. Regarding dimension 1 (Videogame and primary classroom), it was found that at the gender level there are only significant differences in four of the items in favor of men (You know and use the Spanish language appropriately, you master the language of your autonomous community [if any], You know fundamental aspects of Natural Sciences, and, You appreciate the manner of behavior that favors their care).

Table 6. Students T-dimension 1

\begin{tabular}{|c|c|c|c|c|c|}
\hline & & $\mathbf{N}$ & M. & D.T. & \\
\hline \multirow{2}{*}{ Item 11} & W. & 104 & 3.65 & 1.022 & \multirow{2}{*}{$\begin{array}{l}\mathrm{t}=-1.06 ; \mathrm{p}: 0.035 ; \mathrm{Co}- \\
\text { hen's d:- } 0.18\end{array}$} \\
\hline & M. & 65 & 3.82 & .846 & \\
\hline \multirow{2}{*}{ Item 12} & W. & 105 & 3.59 & 1.044 & \multirow{2}{*}{$\begin{array}{l}\mathrm{t}=-2.486 ; \mathrm{p}: 0.028 ; \mathrm{Co}- \\
\text { hen's d: }-0.44\end{array}$} \\
\hline & M. & 66 & 4.02 & .886 & \\
\hline \multirow{2}{*}{ Item 18} & W. & 105 & 3.41 & .885 & \multirow{2}{*}{$\begin{array}{l}\mathrm{t}=2.295 ; \mathrm{p}: 0.045 ; \mathrm{Co}- \\
\text { hen's } \mathrm{d}:-0.34\end{array}$} \\
\hline & M. & 66 & 3.71 & .760 & \\
\hline \multirow{2}{*}{ Item 25} & W. & 105 & 3.62 & .924 & \multirow{2}{*}{$\begin{array}{l}\mathrm{t}=-1.040 ; \mathrm{p}: 0.005 ; \mathrm{Co}- \\
\text { hen's d: }-0.35\end{array}$} \\
\hline & M. & 66 & 3.76 & .703 & \\
\hline
\end{tabular}

Regarding dimension 2 (Attitude towards videogames) (see Table 5), we found differences in favor of men in the items referred to: I like to inform my family and friends about the new videogames that I like; I participate in forums / conferences about videogames; I have participated in some online activity about videogames; I imitate the characters in the video games I play and play video games that are not recommended for your age.
Table 7. Students T-dimension 2

\begin{tabular}{llrlrl}
\hline & & \multicolumn{1}{c}{ N. } & \multicolumn{1}{l}{ M. } & \multicolumn{1}{c}{ D.T. } & \\
\hline \multirow{2}{*}{ Item 40 } & W. & 105 & 1.78 & .920 & t=-2.04; $\mathrm{p}: 0.031 ;$ \\
& M & 64 & 2.36 & 1.187 & Cohen's d: -0.55 \\
& W. & 105 & 1.27 & .593 & $\mathrm{t}=3.394 ; \mathrm{p}: 0.002 ;$ \\
Item 41 & M & 64 & 1.44 & .906 & Cohen's d: -0.24 \\
& W. & 105 & 1.53 & .821 & $\mathrm{t}=3.546 ; \mathrm{p}: 0.001 ;$ \\
Item 42 & M & 64 & 1.97 & 1.297 & Cohen's d: -0.49 \\
& W. & 105 & 1.30 & .652 & $\mathrm{t}=-2.604 ; \mathrm{p}: 0.000 ;$ \\
& M & 64 & 1.55 & 1.038 & Cohen's d: -0.27 \\
& W. & 105 & 1.43 & .807 & $\mathrm{t}=-1.683 ; \mathrm{p}: 0.0015 ;$ \\
& M & 63 & 1.83 & 1.225 & Cohen's d: -0.41 \\
\hline
\end{tabular}

Applying the Variance Analysis test according to the device used for playing, we can verify that there are no significant differences between the participants. Nevertheless, there are some differences found with respect to the number of hours spent playing during the week. Categorizing this variable in 3 again (I do not play, I play from 1 to 5 hours and play more than 5 hours a day), we see the existence of differences in 5 of the items of which it is made, being in all cases in favor of the option "I do not play" (see Table 8).

Table 8. ANOVA dimension 1

\begin{tabular}{|c|c|c|c|c|c|}
\hline & $\begin{array}{c}\text { Game for } \\
\text { hours a day }\end{array}$ & $\mathbf{N}$ & M. & D.T. & $\begin{array}{l}\text { t. and p. of the } \\
\text { favourable } \\
\text { groups }\end{array}$ \\
\hline \multirow{3}{*}{ Item 1} & No play & 31 & 3.00 & .931 & \multirow{3}{*}{$\begin{array}{l}\mathrm{t}=4.786 ; \mathrm{p}=.010 \\
\text { differences in } \\
\text { favour of no game }\end{array}$} \\
\hline & $\begin{array}{l}\text { Game of } 1 \\
\text { to } 5 \text { hours }\end{array}$ & 51 & 3.24 & .790 & \\
\hline & $\begin{array}{l}\text { Game more } \\
\tan 5 \text { hours }\end{array}$ & 89 & 3.51 & .814 & \\
\hline \multirow{3}{*}{ Item 3} & No play & 31 & 3.13 & .991 & \multirow{3}{*}{$\begin{array}{l}\mathrm{t}=4.325 ; \mathrm{p}=.015 \\
\text { differences in } \\
\text { favour of no game }\end{array}$} \\
\hline & $\begin{array}{l}\text { Game of } 1 \\
\text { to } 5 \text { hours }\end{array}$ & 51 & 3.35 & .770 & \\
\hline & $\begin{array}{l}\text { Game more } \\
\tan 5 \text { hours }\end{array}$ & 89 & 3.62 & .833 & \\
\hline \multirow{3}{*}{ Item 12} & No play & 31 & 3.35 & .915 & \multirow{3}{*}{$\begin{array}{l}\mathrm{t}=3.210 ; \mathrm{p}=.043 \\
\text { differences in } \\
\text { favour of no game }\end{array}$} \\
\hline & $\begin{array}{l}\text { Game of } 1 \\
\text { to } 5 \text { hours }\end{array}$ & 51 & 3.78 & 1.137 & \\
\hline & $\begin{array}{l}\text { Game more } \\
\tan 5 \text { hours }\end{array}$ & 89 & 3.88 & .927 & \\
\hline \multirow{3}{*}{ Item 23} & No play & 31 & 2.87 & .957 & \multirow{3}{*}{$\begin{array}{l}\mathrm{t}=3.428 ; \mathrm{p}=.035 \\
\text { differences in } \\
\text { favour of no game }\end{array}$} \\
\hline & $\begin{array}{l}\text { Game of } 1 \\
\text { to } 5 \text { hours }\end{array}$ & 51 & 3.14 & .939 & \\
\hline & $\begin{array}{l}\text { Game more } \\
\tan 5 \text { hours }\end{array}$ & 89 & 3.37 & .946 & \\
\hline \multirow{3}{*}{ Item 26} & No play & 31 & 3.26 & .930 & \multirow{3}{*}{$\begin{array}{l}\mathrm{t}=3.146 ; \mathrm{p}=.0048 \text {. } \\
\text { differences in } \\
\text { favour of no game }\end{array}$} \\
\hline & $\begin{array}{l}\text { Game of } 1 \\
\text { to } 5 \text { hours }\end{array}$ & 51 & 3.51 & .987 & \\
\hline & $\begin{array}{l}\text { Game more } \\
\tan 5 \text { hours }\end{array}$ & 89 & 3.73 & .902 & \\
\hline
\end{tabular}


To establish the differences between groups, a post hoc test (Tukey) was applied, obtaining the following results:

With respect to item 1 we can indicate that there is an effect between the hours played during the week and the development of study habits $[F(2,168)=4,786, p=.010, \eta 2=.05]$. The comparisons between groups reflect the existence of significant differences between those who play more than 5 hours and those who do not play in item $1(\mathrm{t}=2.92, \mathrm{p}=.011)$.

Item 3 (You have confidence in yourself, personal initiative and creativity) has an effect on the hours played during the day $[\mathrm{F}$ $(2,168)=4,325, \mathrm{p}=.015, \eta 2=.04]$. The post hoc test reveals the presence of significant differences between those who play more than 5 hours and those who do not play (item $1, \mathrm{t}=2.77, \mathrm{p}=.017$ ). With respect to item 12 (You master the language of your autonomous community, if any), we find that there is an effect between those who play more than 5 hours and those who do not play [F $(2,168)=3,210, p=.043, \eta 2=.03]$. The comparison between groups indicates differences between those who play more than 5 hours and those who do not $(\mathrm{t}=2.52, \mathrm{p}=.03)$. In the case of item $23[\mathrm{~F}(2,168)=3,428, \mathrm{p}=.035, \eta 2=.03]$, we can note that there is an effect between the hours played during the week and the ability to create audiovisual material, finding differences among teachers in training about those who play more than 5 hours a week and those who play 0 hours $(\mathrm{t}=2.53, \mathrm{p}=.033)$.

Finally, item 26, referred to the development of affective abilities, these are affected by the hours of play during the week, in particular by playing more than 5 hours $[\mathrm{F}(2,168)=3,146, \mathrm{p}=$ $.046, \eta 2=.03$ ], there being significant differences between those who play more than 5 hours during the week and those who do $\operatorname{not}(\mathrm{t}=2.42, \mathrm{p}=.043)$.

With respect to the second dimension (Table 9), in item 36 (I like to play video games) we find the existence of an effect between this and the hours played during the week (more than 5 hours) [F $(2,169)=14,842, \mathrm{p}=.000, \eta 2=.15]$; The comparison between groups indicates that there are differences between those who play more than 5 hours a week $(\mathrm{t}=4.15, \mathrm{p}=.000)$ and those who do not play or play more than 5 hours. In item 38 (I am informed on the Internet about videogames novelties), as in the previous item, there is an effect on what refers to the search for information about videogames and the time spent playing them $[\mathrm{F}(2,169)=4,516$, $\mathrm{p}=.012, \eta \mathrm{2}=.05]$, in which they have shown differences towards those who play more than 5 hours a week $(t=4.15, p=.000)$. In item 39, it has been confirmed that there is an effect between spending more than 5 hours playing a week and consulting the PEGI code that each videogame has on its casing $[F(2,169)=3,748, p=.026$, $\eta 2=.04]$; At the same time, the comparison between groups reveals differences between those who play more than 5 hours a week and those who do not play $(t=.274, p=.037)$. Item 40 reflects that there is an effect between keeping family and friends informed of their preferences in the type of videogames they like to play and the hours they spend playing them $[\mathrm{F}(2,169)=9,003, \mathrm{p}=.000, \eta 2=$ $.09]$ and significant differences have been found between those who play from 1 to 3 and more than 5 hours a week $(t=3.17, p=.005, t$ $=3.65, \mathrm{p}=.001)$ compared to those who do not play. In the case of item 41 , referring to participation in forums / meetings on videogames, by the teachers in training, the tests carried out indicate that there is an effect between this interest and the hours played during the week $[\mathrm{F}(2,169)=3,556, \mathrm{p}=.031, \eta 2=.04]$; the post hoc test shows differences between the groups compared, regarding those who play between 1 and 5 hours $(t=2.6, p=0.027)$ and those who either do not play or play between 1 and 5 hours.

Finally, item 46 (You have used videogames in class by teaching the teacher), shows the existence of an effect between this and playing more than 5 hours a week $[\mathrm{F}(2,169)=4,858, \mathrm{p}=.009, \mathrm{n} 2$ $=.05$ ], finding significant differences in favor of those who play between 1 and 5 hours a week $(\mathrm{t}=3.09, \mathrm{p}=.006)$ play between 1 to 5 hours $(\mathrm{t}=2.6, \mathrm{p}=0.027)$ and those who either do not play or play well between 1 and 5 hours.

Finally, the item 46 (You have used videogames in class by teaching the teacher), introduces the existence of the effect between this and playing more than 5 hours a week $[\mathrm{F}(2,169)=4,858, \mathrm{p}=.009$, $\eta 2=.05]$, finding significant differences in favour of those who play between 1 and 5 hours a week $(t=3.09, \mathrm{p}=.006)$.

Table 9. ANOVA dimension 2

\begin{tabular}{|c|c|c|c|c|c|}
\hline & $\begin{array}{l}\text { Game for } \\
\text { hours a day }\end{array}$ & $\mathbf{N}$ & M. & D.T. & $\begin{array}{l}\text { t. and p. of the fa- } \\
\text { vourable groups }\end{array}$ \\
\hline \multirow{3}{*}{ Item 36} & No play & 31 & \multirow{3}{*}{2.96} & \multirow{3}{*}{1.014} & \multirow{3}{*}{$\begin{array}{l}\mathrm{t}=14.842 ; \mathrm{p}=.000 \text {. } \\
\text { differences in fa- } \\
\text { vour of game more } \\
\text { than } 5 \text { hours }\end{array}$} \\
\hline & $\begin{array}{l}\text { Game of } 1 \text { to } 5 \\
\text { hours }\end{array}$ & 50 & & & \\
\hline & $\begin{array}{l}\text { Game more tan } \\
5 \text { hours }\end{array}$ & 88 & & & \\
\hline \multirow{3}{*}{ Item 38} & No play & 50 & & & \multirow{3}{*}{$\begin{array}{l}\mathrm{t}=4.516 ; \mathrm{p}=.012 . \\
\text { differences in fa- } \\
\text { vour of game more } \\
\text { than } 5 \text { hours }\end{array}$} \\
\hline & $\begin{array}{l}\text { Game of } 1 \text { to } 5 \\
\text { hours }\end{array}$ & 31 & 1.65 & 1.858 & \\
\hline & $\begin{array}{l}\text { Game more tan } \\
5 \text { hours }\end{array}$ & 88 & & & \\
\hline \multirow{3}{*}{ Ítem 39} & No play & 50 & & & \multirow{3}{*}{$\begin{array}{l}\mathrm{t}=3.748 ; \mathrm{p}=.026 . \\
\text { differences in fa- } \\
\text { vour of game more } \\
\text { than } 5 \text { hours }\end{array}$} \\
\hline & $\begin{array}{l}\text { Game of } 1 \text { to } 5 \\
\text { hours }\end{array}$ & 31 & 1.39 & .725 & \\
\hline & $\begin{array}{l}\text { Game more tan } \\
5 \text { hours }\end{array}$ & 88 & & & \\
\hline \multirow{3}{*}{ Item 40} & No play & 31 & & & \multirow{3}{*}{$\begin{array}{l}\mathrm{t}=9.003 ; \mathrm{p}=.000 \text {. } \\
\text { differences in fa- } \\
\text { vour of game more } \\
\text { than } 5 \text { hours }\end{array}$} \\
\hline & $\begin{array}{l}\text { Game of } 1 \text { to } 5 \\
\text { hours }\end{array}$ & 50 & 2.00 & 1.063 & \\
\hline & $\begin{array}{l}\text { Game more tan } \\
5 \text { hours }\end{array}$ & 88 & & & \\
\hline \multirow{3}{*}{ Item 41} & No play & 31 & & & \multirow{3}{*}{$\begin{array}{l}\mathrm{t}=3.556 ; \mathrm{p}=.031 . \\
\text { differences in fa- } \\
\text { vour of game more } \\
\text { than } 5 \text { hours }\end{array}$} \\
\hline & $\begin{array}{l}\text { Game of } 1 \text { to } 5 \\
\text { hours }\end{array}$ & 50 & 1.33 & .730 & \\
\hline & $\begin{array}{l}\text { Game more tan } \\
5 \text { hours }\end{array}$ & 88 & & & \\
\hline \multirow{3}{*}{ Item 46} & No play & 31 & & & \multirow{3}{*}{$\begin{array}{l}\mathrm{t}=4.858 ; \mathrm{p}=.009 . \\
\text { differences in fa- } \\
\text { vour of game more } \\
\text { than } 5 \text { hours }\end{array}$} \\
\hline & $\begin{array}{l}\text { Game of } 1 \text { to } 5 \\
\text { hours }\end{array}$ & 50 & 2.34 & 1.096 & \\
\hline & $\begin{array}{l}\text { Game more tan } \\
5 \text { hours }\end{array}$ & 88 & & & \\
\hline
\end{tabular}

\subsection{Correlation study}

Taking into account the 2 dimensions in which the items are grouped, a correlation study of these has been carried out.

With respect to the first dimension, we must indicate that there is major correlation at a significant level of both $\mathrm{n}=.05$ and $\mathrm{n}=.01$, less in items 9 and 14.

In dimension 2 the correlations between the items that compose it are high at a significance level of both $\mathrm{n}=.05$ and .01 . However, it should be noted that items 45 and 48 have no correlation with any other item in the dimension (Table 10), from which we infer that future teachers consider that educational video games have no relation to the view of general video games and that this latter type is not linked to academic improvement. 
Table 10. Correlation study dimension 2

\begin{tabular}{|c|c|c|c|c|c|c|c|c|c|c|c|c|c|c|}
\hline & & 36 & 37 & 38 & 39 & 40 & 41 & 42 & 43 & 44 & 45 & 46 & 47 & 48 \\
\hline \multirow{3}{*}{36} & $\mathrm{R}$ & 1 & & & & & & & & & & & & \\
\hline & $\mathrm{P}$ & & & & & & & & & & & & & \\
\hline & $\mathrm{R}$ & $.435^{* *}$ & 1 & & & & & & & & & & & \\
\hline 37 & $\mathrm{P}$ & .000 & & & & & & & & & & & & \\
\hline \multirow{2}{*}{38} & $\mathrm{R}$ & $.386^{* *}$ & $.680^{* *}$ & 1 & & & & & & & & & & \\
\hline & $\mathrm{P}$ & .000 & .000 & & & & & & & & & & & \\
\hline \multirow{2}{*}{39} & $\mathrm{R}$ & $.168^{*}$ & $.454^{* *}$ & $.221^{* *}$ & 1 & & & & & & & & & \\
\hline & $\mathrm{P}$ & .029 & .000 & .004 & & & & & & & & & & \\
\hline \multirow{2}{*}{40} & $\mathrm{R}$ & $.563^{* *}$ & $.443^{* *}$ & $.381^{* *}$ & $.371^{* *}$ & 1 & & & & & & & & \\
\hline & $\mathrm{P}$ & .000 & .000 & .000 & .000 & & & & & & & & & \\
\hline \multirow{2}{*}{41} & $\mathrm{R}$ & $.340^{* *}$ & $.684^{* *}$ & $.256^{* *}$ & $.429^{* *}$ & $.430^{* *}$ & 1 & & & & & & & \\
\hline & $\mathrm{P}$ & .000 & .000 & .001 & .000 & .000 & & & & & & & & \\
\hline \multirow{2}{*}{42} & $\mathrm{R}$ & $.443^{* *}$ & $.475^{* *}$ & $.260^{* *}$ & $.227^{* *}$ & $.434^{* *}$ & $.530^{* *}$ & 1 & & & & & & \\
\hline & $\mathrm{P}$ & .000 & .000 & .001 & .003 & .000 & .000 & & & & & & & \\
\hline \multirow{2}{*}{43} & $\mathrm{R}$ & $.361^{* *}$ & $.583^{* *}$ & $.256^{* *}$ & $.347^{* *}$ & $.434^{* *}$ & $.601^{* *}$ & $.422^{* *}$ & 1 & & & & & \\
\hline & $\mathrm{P}$ & .000 & .000 & .001 & .000 & .000 & .000 & .000 & & & & & & \\
\hline \multirow{2}{*}{44} & $\mathrm{R}$ & $.364^{* *}$ & $.416^{* *}$ & $.188^{*}$ & $.227^{* *}$ & $.370^{* *}$ & $.317^{* * *}$ & $.502^{* *}$ & $.426^{* *}$ & 1 & & & & \\
\hline & $\mathrm{P}$ & .000 & .000 & .015 & .003 & .000 & .000 & .000 & .000 & & & & & \\
\hline \multirow{2}{*}{45} & $\mathrm{R}$ & .104 & .004 & .018 & .144 & .133 & -.011 & .045 & .094 & .034 & 1 & & & \\
\hline & $\mathrm{P}$ & .178 & .955 & .812 & .061 & .085 & .889 & .560 & .225 & .657 & & & & \\
\hline \multirow{2}{*}{46} & $\mathrm{R}$ & $.205^{* *}$ & $.220^{* * *}$ & .151 & $.185^{*}$ & $.209^{* * *}$ & $.306^{* *}$ & $.224^{* *}$ & $.253^{* *}$ & .117 & $.174^{*}$ & 1 & & \\
\hline & $\mathrm{P}$ & .007 & .004 & .051 & .016 & .006 & .000 & .003 & .001 & .132 & .023 & & & \\
\hline \multirow{2}{*}{47} & $\mathrm{R}$ & .138 & $.305^{* *}$ & .142 & $.312^{* *}$ & $.280^{* *}$ & $.281^{* *}$ & $.334^{* *}$ & $.266^{* *}$ & $.379^{* *}$ & .114 & $.317^{* *}$ & 1 & \\
\hline & $\mathrm{P}$ & .075 & .000 & .065 & .000 & .000 & .000 & .000 & .000 & .000 & .141 & .000 & & \\
\hline \multirow{2}{*}{48} & $\mathrm{R}$ & .107 & .059 & -.006 & .095 & .012 & .004 & -.011 & .037 & .060 & .031 & -.009 & $-.299^{* *}$ & 1 \\
\hline & $\mathrm{P}$ & .167 & .450 & .942 & .217 & .872 & .963 & .889 & .635 & .437 & .690 & .909 & .000 & \\
\hline
\end{tabular}

**. The correlation is significant at the 0.01 level (bilateral).

*. The correlation is significant at the 0.005 level (bilateral).

\section{DISCUSSION AND CONCLUSIONS}

Learning by means of video games is a reality that is gradually gaining relevance and taking its position in the learning process of students, regardless of the educational level we take into consideration (Marín, 2016; Barr, 2017).

There are a number of factors that determine the relationship of children, teenagers and young people with video games, one of them being the time dedicated to the game. The Entertainment Software Association (2016) reflected that the hours of play of young Americans revolves around 3 hours a week (45\%), as well as the results achieved by Haranto, Toy and Yan (2018), and similarly the ones found which are presented here, since the teachers in training who take part in this study have shown that the hours they dedicate to the game (during the week and at the weekend) do not affect their academic activities, unlike the results obtained in the study of Hartanto, Toh and Yang (2018).

With regard to gender and time dedicated to video games, men are the ones who play the most on weekdays as well as at the weekend (Sierra-Daza \& Fernández-Sánchez, 2017; Giancotti et al., 2018). Men are also those who consider that video games in the primary stage permit knowing and using the Castilian language and that of the corresponding autonomous community, besides they think that they allow the acquisition of fundamen- tal aspects of Nature Sciences and of behaviors that foster their care. Regarding the attitude that they have towards videogames, it should be noted that they present a more favorable attitude towards the communication of the types of videogames they play, their participation in forums or conferences on the subject, imitating the characters of the videogames they play. It is striking that in addition, men claim to play video games that are not recommended for their age more than women.

It is also striking that, as with other digital resources, such as social networks (Marín, Sampedro, \& Vega, 2017), students do not know the players with whom they share games through the network, an aspect that should be studied in depth (Marín, Sampedro, \& Vega, 2017), since they are a fertile ground for the development of disruptive behaviors, harmful to health and / or harassment (Gentile, Bender, \& Anderson, 2017; Tang \& Fox, 2017).

In turn, the use of video games in the primary classroom will allow them to generate favorable opinions on equal rights between men and women, as well as help them to improve or master the language.

One area that is favored by the use of video games is the area of mathematics. The teachers in training consider that in the elementary classroom they help in both mental and cal- 
culation learning, which at the same time will allow them to apply that knowledge to daily life (del Moral, Fernández, \& Guzmán-Duque, 2016).

Unlike the work of Anderson and Gentile (2014), participants indicate that the use of video games in the primary classroom can help develop behaviors that are contrary to violence, from which we infer that they could be a resource when designing Modulation programs for school coexistence.

In line with the research developed by Stinchcombe et al. (2017) with 50 students from the University of Ottawa (Canada), which indicated that the use of driving simulators increased the cognitive and perceptive skills of Spanish students, it is also considered that the use of video games, in this case driving simulators such as Gran Turismo (created for Play Station), enables a proper attitude towards the prevention of traffic accidents.

It is relevant that the participants do not agree with the claim that videogames create discrimination towards people with disabilities (Calvo-Ferrer \& Belda-Medina, 2015; Castro-Sánchez, Chacón-Cubero, \& Padial-Ruz, 2017; Wartenweiler, 2018) or help them function properly in everyday situations using a foreign language (Brazo, Muñoz, \& Castro, 2018).

Finally, in regard to the hours that they spend playing, teachers in training play more than 5 hours a week, therefore we can infer that young people today do not present an addictive behavior or a problematic use of these as is reflected in the works by Chamarro et al. (2014) and Torres-Rodríguez and Carbonell (2015).

\section{REFERENCES}

Adukaite, A., van Zyl, I., Er, S., \& Cotani, L. (2017). Teacher perception on the use of digital gamified learning in tourism education: The case of South Africa secondary schools. Computer \& Education, 111, 172-190. doi:10.1016/j. compedu.2017.04.008

Anderson, C. A., \& Gentile, D. A. (2014). Violent video effects on aggressive thoughts, feelings, physiology, and behavior. In D. A. Gentile (Ed.), Media violence and children (2nd ed., pp. 229-270). Westport, CT: Praeger.

Aznar-Díaz, I., Raso-Sánchez, F., \& Hinojo-Lucena, M. A. (2017). Percepciones de los futuros docentes respecto al potencial de la ludificación y la inclusión de los videojuegos en los procesos de enseñanza-aprendizaje. Educar, 53(1), 1128. doi:10.5565/rev/educar.840

Barr, M. (2017). Video games can develop graduate skills in higher education students: A randomised trial. Computes \& Education, 80, 86-97. doi:10.1016/j. compedu.2017.05.016

Brazo, A. I., Muñoz, J. M., \& Castro, C.(2018). Aprendiendo léxico y ortografía francesa en la universidad mediante el videojuego SRIBBLENAUTS. EDMETIC, Revista de Educación Mediática y TIC, 7(2), 18-36. doi:10.21071/ edmetic.v7i2.7201

Calvo-Ferrer, J. R., \& Belda-Medina, J. R. (2015). Análisis de la satisfacción del alumnado de L2 con respecto a la adquisición de terminología especializada por medio de videojuegos: estudio de caso. Porta Linguarum, 24, 179-190. Retrieved from https://rua.ua.es/dspace/bitstream/10045/48627/1/2015 Calvo_Belda_Porta-Linguarum.pdf

Cámara, A. M., Díaz, E. M., \& Ortega, J. (2017). Aprendizaje servicio en la universidad: ayudando a la escuela a atender a la diversidad a través de las TIC. Bordón, 69(3).

Cañón, R., Cantón, I., Arias, A. R., \& Baelo, R. (2017). Initiation into Teaching from the Perspective of Primary School Teachers: Differences Between Newly Qualified and Experienced Teachers. Journal of New Approaches in Educational Research, 6(2), 103-111. doi:10.7821/naer.2017.7.202

Castro-Sánchez, M., Chacón-Cuberos, R., \& Padial-Ruz, R. (2017). Exergames y discapacidad. ESHPA-Education, Sport, Health and Physical Activity, 1(1), 2-9.

Chamarro, A., Carbonell, X., Manresa, J. M., Muñoz-Miralles, R., Ortega-González, R., López-Morrón, M. R., Batalla-Martínez, C., \& Toran-Monserrat, P. (2014). El Cuestionario de Experiencias Relacionadas con los Videojuegos (CERV): Un instrumento para detectar el uso problemático de videojuegos en adolescentes españoles. Adicciones, 26(4), 303-311. doi:10.20882/adicciones.31

DeCamp, W., \& Ferguson, Ch.J. (2017). The impact of degree of exposure to violent video games, family background, and other factors on youth violence. Journal of Youth and Adolescence, 46(2), 388-400. doi:10.1007/s10964-016-0561-8

Del Moral, E., Fernández, L. C., \& Guzmán-Duque, A. P. (2016). Proyecto game to learn: aprendizaje basado en juegos para potenciar las inteligencias lógicom- atemática, naturalista y lingüística en educación primaria. Píxel-Bit. Revista de Medios y Educación, 49, 177-193. doi:10.12795/pixelbit.2016.i49.12

Del Moral, M. E., \& Fernández, L. C. (2015). Videojuegos en las aulas: implicaciones de una innovación disruptiva para desarrollar las Inteligencias Múltiples 1/Video games in the classrooms: implications of a disruptive innovation to develop the Multiple Intelligences. Revista Complutense de Educación, 26, 97-118.

Del Moral, E., Guzmán, A. P., \& Fernández, L. C. (2018). Game-Based Learning: Increasing the Logical-Mathematical, Naturalistic, and Linguistic Learning Levels of Primary School Students. Journal of New Approaches in Educational Research, 7(1), 31-39, doi:10.7821/naer.2018.1.248

Gentile, D. A., Bender, P. K., \& Anderson, C.A. (2017). Violent video game effects on salivary cortisol, arousal, and aggressive thoughts in children. Computers in Human Behavior, 70, 39-43. doi:10.1016/j.chb.2016.12.045

Giancotti, G. F., Fusco, A., Rodio, A., Capranica, L., \& Cortis, C. (2018). Energy expenditure and perceived exertion during active video games in relation to player mode and gender. Kinesiology, 50(1). doi:10.26582/k.50.1.3 Retrieved from https://hrcak.srce.hr/ojs/index.php/kinesiology/article/view/6580

Greitemeyer, T. (2018). The spreading impact of playing violent games on aggression. Computers in Human Behaviour, 80, 2016-219. doi:10.1016/j. chb.2017.11.022

Hartanto, A., Toh, W. X., \& Yang, H. (2018).Context counts: The different implications of weekday and weekend video gaming for academic performance in mathematics, reading, and science. Computes \& Education, 120, 51-63. doi:10.1016/j.compedu.2017.12.007

Herrero, M., del Moral, M E., \& Torralba-Burrial, A. (2017). Aprendizajes científicos y educación ambiental en entornos lúdicos: potencialidad de un videojuego en línea sobre desastres naturales para la educación formal de maestros. In Actas del V Congreso Internacional de Videojuegos y Educación (CIVE'17). Retrieved from https://riull.ull.es/xmlui/bitstream/handle/915/6680/CIVE17 paper_16.pdf?sequence $=1 \&$ isAllowed $=\mathrm{y}$

Loza, J. E., Salinas, V., \& Glasserman, L. D. (2017). Rendimiento académico de los alumnos de secundaria que participan en el programa de aulas digitales. EDMETIC, Revista de Educación Mediática y TIC, 6(2), 60-80. doi:10.21071/ edmetic.v6i2.5791

Marín, V. (2016). ¿Hay posibilidades de trabajar la inclusión a través de los videojuegos? Revista del Salomé, 1(2), 67-87.

Marín, V., \& Martín, J. (2014). ¿Podemos utilizar los videojuegos para el desarrollo del currículo de la etapa de infantil? NAER, Journal of New Approaches in Educational Research, 3(1), 20-25

Marín, V., \& Sampedro, B. E. (2016). Innovando en el aula de Educación Primaria con GT 6. International Journal of Technology and Educational Innovation, 2(1), 13-19. doi:10.20548/innoeduca.2016.v2i1.1061 Retrieved from http:// revistas.uma.es/index.php/innoeduca/article/view/1061/1870

Marín, V., Sampedro, B. E., \& Vega, E. (2017). Estudio psicométrico de la aplicación del Internet Addiction Test con estudiantes universitarios españoles. Contextos Educativos, Núm. Extraordinario, 20(2), 147-161. doi:10.18172/con.3067

Martín, M. (2015). Videojuegos y aprendizaje colaborativo. Experiencias en torno a la etapa de Educación Primaria. Enseñanza \& Teaching, 16(2), 69-89. doi:10.14201/eks20151626989

Mateo, J. (2012). La investigación ex post-facto. In R. Bisquerra (Coord.), Metodología de investigación educativa. (pp. 195-229). Madrid: La Muralla.

Morales, M., Trujillo, J. M., \& Raso, F. (2016). Percepción del profesorado y alumnado universitario ante las posibilidades que ofrecen las TIC en su integración en el proceso educativo: reflexiones, experiencias e investigación en la Facultad de educación de Granada. EDMETIC, Revista de Educación Mediática y TIC, 5(1), 113-142. doi:10.21071/edmetic.v5i1.4019

Sabariego, M. (2012). La investigación educativa: génesis, evolución y características. In R. Bisquerra (Coord.), Metodología de la investigación educativa (pp. 51-87). Madrid: La Muralla.

Serna-Rodrigo, R., \& Rovira-Collado, J. (2016). Aportaciones de los videojuegos a la Educación Literaria. In Actas de las XVI Jornadas de Xarxes d'Investigacio en docencia universitaria. Alicante: Instituto de Ciencias de la Educación. Retrieved from https://rua.ua.es/dspace/bitstream/10045/59355/1/XIV-Jornadas-Redes-ICE 056.pdf

Sierra-Daza, M. C., \& Fernández-Sánchez, M. R. (2017). Percepción de los videojuegos en educación social: una visión de género. International Journal of Educational Research and Innovation (IJERI), 7, 135-148.

Stinchcombe A., Kadulina, Y., Lemieux, Ch., Aljied, R., \& Sylvain, G. (2017). Driving is not a game: Video game experience is associated with risk taking behaviours in the driving simulator. Computers in Human Behavior, 69, 415 420. doi:10.1016/j.chb.2016.12.006

Tang, W. Y., \& Fox, J. (2016). Men's harassment behavior in online video games: Personality traits and game factors. Aggressive Behavior, 42(6), 513-521. doi 10.1002/ab.21646

Tarancón, B. (2017), Implementación de un modelo de Entorno Personal de Aprendizaje en el Grado en Educación. Estudio de caso. EDMETIC, Revista de Educación Mediática y TIC, 6(2), 232-254. doi:10.21071/edmetic.v6i2.6933 
Wartenweiler, T. (2018). Serious play in education for social justice - An exploratory study. Journal of New Approaches in Educational Research, 7(1), 61-69. doi:10.7821/naer.2018.1.260

How to cite this article: Marín-Díaz, V., Morales-Díaz, M., \& Reche-Urbano, E. (2019). Educational Possibilities of Video Games in the Primary Education Stage According to Teachers in Training. A Case Study. Journal of New Approaches in Educational Research, 8(1), 4249. doi:10.7821/naer.2019.1.330 